\title{
Pengaruh Pemberitaan Media Massa Pada Motivasi Olahragawan
}

\author{
Heny Setyawati ${ }^{a}$ \\ ${ }^{a}$ Universitas Negeri Semarang, Semarang, Indonesia \\ *Corresponding author: henysetyawati@mai.unnes.ac.id
}

\section{A RTICLE INFO}

\section{Article history:}

Received 17 Maret 2017

Received in revised form 25 Maret

2017

Accepted 29 April 2017

Keywords:

News, mass media, motivation, athletes,

\begin{abstract}
A B S T R A C T
Sports performance is influenced by the existence of positive and negative expectations on a particular thing. Positive expectations will have a positive impact on appearance, as well as negative expectations will have a negative impact on appearance. Positive Expectations on Sportsmen are influenced by their motivation in exercising. Great motivation will result in maximum performance. One external factor that could affect motivation to the athlete is coverage in the mass media. The purpose of this study is to determine the influence of mass media coverage on the motivation of athletes. The research used qualitative design with phenomenology approach, that is reducing psychological experience of sportsman related to news in mass media. The method used to obtain data by conducting interviews, observation and documentation. The influence of mass media coverage on athletes, especially in improving degree in execution of tasks. Positively perceived news in the mass media build motivates the sportsman to try to get better. They become motivated and more enthusiastic in practicing and competing. The condition implies that when the sportsman appears to be news material in the mass media can positively increase his spirits both in practice and in the face of the game. On the other hand the negative news in the mass media did not make them pull away or down. Instead of negative news there is actually a motivation for them to show that they can be more achievers again and not as reported. It is also a correction for them to improve themselves. Suggestions that can be drawn from the conclusions and implications of this study are as follows: For athletes, can be a reference for how to process information appropriately, to develop motivation. For the media, to help the athlete through the construction of news coverage in the mass media to build athletes motivation
\end{abstract}

\section{Pendahuluan}

Aspek psikologi menjadi hal yang sangat penting untuk diperhatikan dan mendapatkan penanganan dengan segera dalam pembinaan olaharaga. Ketidak seriusan dalam penanganan dalam aspek psikologi menjadi salah satu faktor ketidaksiapan olahragawan pada saat bertanding. Pada saat bertanding olahragawan akan mengalami tekanan psikologis yang tinggi. Tekanan psikologis yang tinggi pada saat pertandingan akan mengakibatkan menurunnya konsentrasi olahragawan pada saat pertandingan. "Persiapan psikologi dibutuhkan untuk memastikan kinerja fisik yang optimal" (Bompa, 2009:5). Peran aspek psikologi dalam pencapaian suatu prestasi semakin dirasakan dan dibutuhkan oleh mereka yang berkecimpung dalam elite sports. "Semua latihan fisik yang telah dilakukan dengan semua prosedur latihan yang baik, akan sia-sia kalau aspek kejiwaan tidak diikutsertakan" (Gunarsa, 2008: 3). "Lars-Erik Unestahl dari swedia mengatakan bahwa latihan mental dalam olahraga harus dianggap sama pentingnya dengan latihan fisik" (dalam Gunarsa, 2008: 4).

Olahragawan adalah manusia biasa yang bukan hanya memiliki raga, tetapi juga memiliki jiwa dan emosi. Olahragawan sering mengalami gejolak-gejolak mental dan sering berada dalam situasi atau keadaan yang penuh stres yang mencekam dan berpengaruh pada prestasinya. Aspek mental penting untuk dilatih dan dikelola dengan sengaja, dengan betul, sitematik, dan berencana. Peranan penting faktor psikologis dalam olahraga juga dikuatkan oleh Harsono (2008: 50) yang mengatakan bahwa "dalam pertandingan, kesuksesan sedikitnya ditentukan oleh $80 \%$ faktor mental dan hanya $20 \%$ faktor yang lain".

Menurut Butler "Kinerja olahraga sangat dipengaruhi oleh adanya harapan yang positif dan negatif pada suatu hal tertentu. Harapan positif akan membawa dampak positif pada penampilan, demikian juga harapan negatif akan membawa dampak negatif pada penampilan" (1996:46). Sementara "positif dan negatifnya harapan seseorang juga dipengaruhi oleh keyakinan diri orang tersebut bahwa dia akan mampu menyelesaikan atau merampungkan tugasnya dengan baik" (Jarvis, 2005:68).

Dari berbagai ketidakberhasilan olahragawan dalam suatu even pertandingan ditengarai aspek mental tersebut yang menjadi penyebab utamanya. Kemampuan fisik dan keterampilan yang dilatihkan pada olahragawan selama bertahun-tahun tidak akan ada artinya bila olahragawan tidak mempunyai ketahanan mental yang tangguh.

Kondisi psikologis olahragawan dalam bentuk ketahanan mental yang tangguh saat melaksanakan pertandingan, menjadi satu kunci penting yang menentukan keberhasilannya. Pertandingan-pertandingan yang terjadi dalam tekanan psikologis yang tinggi akan sangat mengganggu konsentrasi olahragawan. Akibatnya olahragawan sering terlihat melakukan kesalahan-kesalahan yang sama berulang-ulang.

Terbentuknya ketahanan mental yang tangguh pada olahragawan pada dasarnya dipengaruhi oleh dua faktor, yaitu faktor internal dan faktor eksternal. Faktor internal adalah kondisi internal olahragawan termasuk didalamnya struktur kepribadian. Sementara faktor eksternal olahragawan adalah kondisi lingkungan olahragawan, baik lingkungan keluarga, lingkungan latihan maupun masyarakat.

Salah satu faktor yang menjadi bagian dari lingkungan masyarakat 
adalah adanya pemberitaan atau penayangan berbagai hal terkait dengan keberadaan olahragawan tersebut, baik menyangkut prestasi maupun permasalahan sekitar kehidupan pribadi dan aktivitas olahraganya melalui media massa.

Untuk mendapatkan data nyata dan jelas mengenai pengaruh media massa terhadap motivasi olahragawan, telah dilakukan foccus group discussion (FGD), Dari hasil FGD di atas bisa tarik benang merah bahwa pers mempunyai empat fungsi yaitu: memberikan informasi, memberikan pendidikan, memberikan hiburan dan melakukan fungsi kontrol sosial. Pemberitaan di media massa sudah merupakan hasil kontruksi bukan lagi apa adanya, ada banyak kepetingan yang masuk didalamnya. Selalu ada keberpihakan media pada pihak tertentu yang prosentasenya tergantung pada situasi dan kondisi.

Olahraga menjadi salah satu komoditas dari media, olahraga sudah dikomodifikasikan, dijadikan barang dagangan oleh media. Secara konseptual apa yang disampaikan media harus memiliki tiga parameter, yaitu harus berdasarkan fakta, bisa diverifikasi dan diuji. Muara dari semua itu adalah truthfull bahwa apa yang disampaikan media itu mengandung kebenaranan (Turnomo, FGD, 25 Januari 2012).

Menurut pelatih dan pembina olahraga media berperan penting dalam meningkatkan motivasi olahragawan. Media massa merupakan bagian tak terpisahkan dari pembinaan olahraga, yang harus dikelola dengan baik sehingga memberikan efek positif dari tujuan pembinaan itu sendiri.

Dari sisi olahragawan mereka merasa senang ketika diberitakan di media massa. Berita di media massa menjadikan mereka lebih termotivasi dan merasa dirinya terkenal. Berita positif yang dimuat di media massa menjadikan mereka bangga, sementara berita yang memuat kekurangan-kekurangannya menjadi bahan bagi mereka untuk melakukan introspeksi dan memperbaiki diri. Ada kalanya berita negatif di media massa juga bisa menjadi motivasi bagi olahragawan dibandingkan berita positif.

Permasalahan dalam penelitian ini adalah pemberitaan media massa dan motivasi olahragawan. Pemberitaan di media massa mengenai olahragawaan pada saat mereka meraih kemenangan dipersepsi sebagai pemberitaan yang positif oleh olahragawan. Sementara pemberitaan mengenai kekalahan dalam pertandingan dan kritik dipersepsi sebagai pemberitaan negatif.

Mengacu pada kondisi tersebut objek penelitian ini adalah pemberitaan media massa dan motivasi olahragawan. Sasaran penelitian adalah olahragawan yang sering menjadi bahan pemberitaan di media massa dan minimal mempunyai prestasi di tingkat nasional. Olahragawan tersebut terdiri dari olahragawan dari cabang olahraga indivual dan beregu dan dari jenis olahraga invasi, non invasi, body contact dan non body contact.

Ruang lingkup pemberitaan media massa yang dikaji disini tidak hanya mengarah pada media tertentu, akan tetapi menyeluruh menyangkut media massa cetak dan non cetak. Penelitian dilaksanakan dengan mengkaji pengaruh pemberitaan media massa dan motivasi olahragawan pada masa lalu hingga sampai sekarang, sehingga penelitian ini termasuk penelitian ex post fakto.

Rumusan masalah dalam penelitian ini adalah: bagaimanakah pengaruh pemberitaan di media massa pada motivasi olahragawan?

Tujuan penelitian ini adalah untuk mengetahui: pengaruh pemberitaan media massa dan motivasi olahragawan.

\section{Metode}

Pendekatan penelitian yang dipakai adalah pendekatan fenomenologi, yaitu mendeskripsikan pemaknaan umum dari sejumlah individu terhadap berbagai pengalaman hidup mereka terkait dengan konsep dan fenomena (Creswell, 2015:105). Tujuan utama dari fenomenologi adalah untuk mereduksi pengalaman olahragawan dalam aktivitasnya dan pemberitaan media massa.
Penelitian diarahkan untuk menggali dan menafsirkan pengalaman hidup olahragawan dalam aktivitasnya dan pemberitaan media massa. Untuk itu peneliti mengidentifikasi dan mengumpulkan data dari olahragawan yang telah mengalami fenomena pemberitaan di media massa kemudian mengembangkan deskripsi gabungan tentang esensi dari pengalaman tersebut bagi semua individu. Deskripsi tersebut terdiri dari apa yang telah mereka alami, dan bagaimana mereka memaknai dan merekonstruksi dalam kehidupannya.

Fenomena yang diteliti dalam penelitian ini adalah mengenai pemberitaan yang ada di media massa mengenai olahragawan dari sudut perspektif partisipan. Partisipan adalah orang-orang yang diajak berwawancara, diobservasi, diminta memberikan data, pendapat, pemikiran, persepsinya (Sukmadinata, 2006: 94). Partisipan dalam penelitian ini adalah olahragawaan dalam berbagai cabang olahraga.

Penelitian ini dilakukan untuk mendapatkan gambaran yang mendalam serta melakukan analisis mengenai pengaruh pemberitaan media massa pada motivasi olahragawan. Studi ini juga melakukan identifikasi dan analisis mendalam terhadap motivasi olahragawan. Secara fokus untuk memperoleh gambaran faktual mengenai pengolahan informasi olahragawan dalam memaknai, mempersepsi dan merespon pemberitaan dirinya di media massa. Data digali melalui pengalaman yang telah dialami olahragawan di masa lalu hingga sampai sekarang, sehingga penelitian ini termasuk penelitian ex post facto.

Data penelitian dikumpulkan dari latar situasi sosial dan kultural yang alami sebagai sumber data langsung. Data dimaknai dengan melakukan pendalaman terhadap fakta yang diperoleh peneliti di lapangan. Peneliti terjun langsung ke lapangan kedalam situasi partisipan, hal ini dilakukan untuk menemukan sekaligus mendeskripsikan dan menganalisis data secara menyeluruh dan utuh mengenai pengolahan informasi olahragawan terhadap pemberitaan di media massa. Dari data penelitian dihasilkan gambaran mengenai implikasi empirik dan faktual mengenai pengaruh pemberitaan di media massa, baik positif maupun negatif terhadap motivasi olahragawan.

Fokus dalam penelitian ini adalah pengaruh pemberitaan media massa pada motivasi olahragawan dari perspektif persepsi olahragawan. Pemberitaan di media massa mengenai olahragawaan pada saat mereka meraih kemenangan dipersepsi sebagai pemberitaan yang positif oleh olahragawan. Sementara pemberitaan mengenai kekalahan dalam pertandingan dan kritik dipersepsi sebagai pemberitaan negatif. Dari fenomena tersebut bahwa pemberitaan di media massa baik pemberitaan positif dan negatif, ternyata dipersepsi secara berbeda beda oleh olahragawan. Hal ini menjadi bahan kajian yang menarik untuk dikaji lebih lanjut. Pemberitaan yang sama bisa dipersepsi berbeda oleh olahragawan, persepsi yang berbeda tersebut tentunya dipengaruhi oleh bagaimana aktivitas pemrosesan informasi olahragawan pada pemberitaan media massa. Aktivitas pemrosesan informasi pada olahragawan dipengaruhi oleh berbagai faktor diantaranya adalah jenis olahraga, level prestasi, dan kepribadian.

Mengacu pada kondisi tersebut objek penelitian ini adalah pengaruh pemberitaan media massa pada motivasi olahragawan. Sasaran penelitian adalah olahragawan yang sering menjadi bahan pemberitaan di media massa dan minimal mempunyai prestasi di tingkat nasional. Olahragawan tersebut terdiri dari olahragawan dari cabang olahraga indivual dan beregu dan dari jenis olahraga invasi, non invasi, body contact dan non body contact.

Ruang lingkup pemberitaan media massa yang dikaji disini tidak hanya mengarah pada media tertentu, akan tetapi menyeluruh menyangkut media massa cetak dan non cetak. Penelitian dilaksanakan dengan mengkaji pemberitaan media massa dan motivasi olahragawan pada masa lalu hingga sampai sekarang, sehingga penelitian ini termasuk penelitian ex post fakto. 
Sesuai dengan tahapan-tahapan dalam rancangan penelitian kualitatif, teknik yang ditempuh dalam pengumpulan data penelitian menggunakan teknik (1) wawancara, yakni wawancara terbuka (open interview), (2) observasi, yakni observasi atau pengamatan terbuka (open observation) dan observasi partisipasi sebagai pengamat, (3) studi dokumentasi (study of documentation)

Analisis data dalam penelitian ini dilakukan sejak awal sampai dengan berakhirnya penelitian. Analisa data dilakukan untuk mencari dan menyusun secara sistematis data hasil wawancara, catatan lapangan, studi dokumentasi dengan cara mengorganisasikan kedalam kategori, menjabarkan kedalam unit-unit, melakukan sintesis, menyusun kedalam pola, memilih yang penting, membuat simpulan sehingga mudah dipahami oleh peneliti maupun orang lain (Sugiyono, 2006:337). Melalui analisis data ini diharapkan dapat ditemukan nilai-nilai yang terkandung dalam setiap informasi atau data-data yang telah terkumpul.

Teknik analisis data yang digunakan dalam penelitian ini adalah teknik analisis data kualitatif, mengikuti konsep yang diberikan Miles dan Huberman (1984) yang menegaskan bahwa aktivitas dalam analisis data kualitatif dilakukan secara interaktif dan berlangsung secara terus menerus sampai tuntas, sehingga datanya sudah jenuh. Aktivitas dalam analisis data, yaitu data reduction, data display, dan data conclusion drawing/verification (Sugiyono, 2009: 91-99).

\section{Hasil dan diskusi}

Pengaruh Pemberitaan Positif Di Media Massa pada Motivasi Olahragawan Dari sudut pandang atau perspektif olahragawan mereka mempersepsi bahwa pemberitaan positif yang muncul di media massa biasanya terjadi pada saat mereka meraih kemenangan. Ketika mereka meraih suatu kemenangan dalam pertandingan maka semua media massa memuat secara besar besaran berita kemenangannya. Olahragawan diulas dari berbagai aspek baik dari sisi pribadinya sebagai individu, keluarganya sampai kepada cabang olahragannya. Fotonya akan dipampangkan di banyak media massa, banyak sanjungan dan rasa bangga atas kemenangan yang diraihnya. Di media massa banyak profil yang mengulas olahragawan tersebut dari berbagai sudut pandang, yang intinya adalah bentuk pemberitaan yang sangat positif dan membesar besarkan olahragawan. Kadang kala pemberitaan yang muncul juga sering berlebihan mereka dipuja, disanjung, mereka diberitakan sebagai sebuah model yang perlu dielu-elukan. Mereka mendapat hadiah dan bonus dan hampir seluruh aktivitasnya diberitakan dan diulas dengan bagus di media massa. Banyak media massa yang menayangkan profilnya secara utuh, dimulai dari bagaimana dia memulai latihan, proses latihan yang dijalani, bahkan sampai pada aktivitas kehidupan sehari harinya. Sehingga pemberitaan juga kadang menjadi sedikit atau terlalu berlebihan. Olahragawan dikejar-kejar untuk diwawancarai, bahkan ketika media massa tidak mendapatkan kesempatan untuk mewawancarai olahragawan tersebut maka mereka bisa mengampil materi dan foto untuk ditayangkan dalam media massanya dari media massa lain. Sehingga di berbagai media massa akan terlihat atau ditayangkan gambar atau foto dan berita yang relatif hampir sama atau seragam. Media massa berlomba-lomba menayangkan pemberitaan mengenai olahragawan tersebut. Dari pemberitaan seperti itu, yang dimaknai sebagai pemberitaan yang positif oleh olahragawan akan mempengaruhi motivasi oleh olahragawan.

Pemberitaan di media massa yang dipersepsi positif oleh olahragawan dianggap bisa memberikan motivasi kepada olahragawan untuk berusaha menjadi lebih baik lagi. Kondisi ini menyiratkan bahwa ketika olahragawan muncul menjadi bahan berita di media massa secara positif bisa menambah semangatnya baik dalam berlatih maupun dalam menghadapi pertandingan. Selain itu pemberitaan di media massa juga dimaknai positif oleh olahragawan karena bisa meningkatkan harga dirinya dari orang yang bukan siapa siapa menjadi orang yang terkenal dengan prestasinya. Sementara dalam olahraga beregu pemberitaan positif di media massa akan sangat berdampak baik bagi peningkatan motivasi anggota tim. Dari berbagai hasil tersebut mengindikasikan bahwa pemberitaan di media masa bisa meningkatkan motivasi olahragawan untuk berusaha lebih baik lagi. Mereka menjadi lebih bersemangat dan timbul motivasi lebih ketika diberitakan di media massa. Menurut teori belajar sosial, interaksi antara perilaku dan lingkungan, yang memusatkan diri pada pola perilaku yang dikembangkan individu untuk menguasai lingkungannya. Individu tidak didorong oleh kekuatan internal, dan tidak bereaksi pasif terhadap stimulasi eksternal. Munculnya kondisi ini menjadi menarik, karena apa yang dipersepsi olahragawan terhadap liputan media kemudian muncul menjadi bentuk motivasi bagi olahragawan untuk berusaha menjadi lebih baik. Permberitaan media massa yang dimaknai positif oleh olahragawan nyata bisa memotivasi olahragawan untuk berusaha agar bisa lebih baik lagi.

Pengaruh Pemberitaan Negatif Di Media Massa pada Motivasi Olahragawan. Dari sudut pandang atau perspektif olahragawan mereka mempersepsi bahwa pemberitaan negatif yang muncul di media massa biasanya terjadi pada saat mereka mengalami kekalahan, kegagalan, cedera dan pada saat mereka sedang mempunyai permasalahan pribadi. Ketika mereka mengalami kegagalan dalam pertandingan maka semua media massa memuat secara besar besaran berita kegagalannya. Olahragawan diulas dari berbagai aspek baik dari sisi pribadinya sebagai individu, keluarganya sampai kepada cabang olahragannya. Banyak kritik dan saran bahkan celaan-celaan di media massa. Dari komentator sampai masyarakat awam memberikan komentar akan kegagalan atau kekalahannya. Banyak komentar menyalahkan atas kekalahan olahragawan tersebut. Walaupun juga ada bentuk simpati atau dukungan terhadap mereka, akan tetapi pemberitaan tersebut tetap mereka anggap sebagai pemberitaan yang negatif. Pemberitaan seperti itulah yang dimaknai dan dipersepsi sebagai pemberitaan negatif oleh olahragawan dan mempengaruhi motivasi olahragawan.

Dalam aspek motivasi pemberitaan di media massa yang dipersepsi negatif oleh olahragawan, bisa memberikan pengaruh negatif juga sebaliknya memberikan pengaruh negatif. Pengaruhnya akan menjadi positif atau negatif tergantung pada olahragawan sendiri. Pemberitaan yang negatif di media massa akan menjadikan olahragawan jatuh mentalnya atau sebaliknya bisa menimbulkan motivasi pada olahragawan untuk berusaha mempernbaiki diri, sangat tergantung pada ketahan mental olahragawan. menjadi motivasi atau semakin membuat mereka jatuh.

Respon olahragawan terhadap pemberitaan negatif ternyata bisa berpengaruh positif maupun negatif bagi olahragawan. Mereka menyadari bahwa diberitakan negatif maupun positif, hal itu tergantung pada masing masing. Terutama dalam olahraga tim, pada saat salah satu anggota tim atau timnya diberitakan negatif, kalau mereka tetap kompak akan terasa enak.

Ada kalanya pemberitaan negatif bisa menjadi motivasi bagi olahragawan untuk menunjukkan bahwa mereka bisa lebih berprestasi lagi dan tidak seperti yang diberitakan. Selain itu juga menjadi koreksi bagi mereka untuk memperbaiki diri.

Menurut KB, media massa menilai dan mengatakan dirinya adalah olahragawan yang arogan dan kasar, namun dari kondisi tersebut justru dirinya bisa mengontrol diri dan belajar untuk harus berbuat apa, agar tidak mendapatkan kritik lagi. Dalam hal ini olahragawan tersebut sudah bisa menikmati dan mengolah kritik tersebut dengan baik. Dia dicerca dan dikritik tapi dia tidak marah, dai bisa menerima karena kenyataan memang seperti itu.

Tidak semua kritikan media massa itu menurunkan olahragawan, kritikan itu justru memacu mereka untuk mengkontrol diri dengan baik. Menurut pelatih yudo, dia mengamati bahwa kritik dari media massa termasuk kritik mekanik banyak merubah hal negatif dari olahragawan, yang tadinya banyak membuat ulah tapi karena kritikan berangsur berubah menjadi baik. Dia tidak marah, tetapi justru berterimakasih 
karena menjadi tahu kekurangannya. Pemberitaan negatif ternyata bias mendatangkan hal yang negatif juga hal yang positif.

Menurut pelatih $\mathrm{KB}$, kalau ada pemberitaan di media massa yang negatif biasanya koran tersebut hanya akan dilempar tidak dibaca oleh $\mathrm{KB}$, pemberitaan seperti itu sudah dianggap biasa olehnya. Akan tetapi kalau pemberitaan yang dimuat negatif yang berisi kritikan, maka koran tersebut akan dibaca dengan serius dan kemudian mereka akan berdiskusi. Justru dengan kondisi tersebut olahragawan belajar, mengkoreksi kekurangan dirinya. Kenyataan tersebut memberikan fakta bahwa pemberitaan yang negatif juga bisa memberikan motivasi bagi olahragawan.

\section{Simpulan}

Berdasarkan hasil penelitian dan pembahasan mengenai pengaruh pemberitaan media massa pada motivasi olahragawan dapat dikonstruksi konsep baru mengenai posisi media massa pada penampilan olahragawan. Pemberitaan media massa yang positif bisa membangun motivasi olahragawan. Pemberitaan media massa yang negatif yang didasarkan pada kenyataan faktual akan dimaknai positif oleh olahragawan. Media bisa mengambil peran melalui kontruksi pemberitaannya untuk membantu olahragawan membangun ketahanan mentalnya.

Pengaruh pemberitaan media massa pada olahragawan khususnya dalam meningkatkan derajad dalam pelaksanaan tugas. Pemberitaan yang dipersepsi positif di di media massa membangun memotivasi olahragawan untuk berusaha menjadi lebih baik. Mereka menjadi termotivasi dan lebih semangat dalam berlatih dan bertanding. Kondisi tersebut menyiratkan bahwa ketika olahragawan muncul menjadi bahan berita di media massa secara positif bisa menambah semangatnya baik dalam berlatih maupun dalam menghadapi pertandingan.

Selain itu pemberitaan di media massa juga dimaknai positif oleh olahragawan karena bisa meningkatkan harga dirinya dari orang yang bukan siapa siapa menjadi orang yang terkenal dengan prestasinya. Selain itu pemberitaan juga memotivasi olahragawan untuk bisa memperoleh hasil yang lebih baik lagi.

Sementara dalam olahraga beregu pemberitaan positif di media massa akan sangat berdampak baik bagi peningkatan motivasi anggota tim. Hal ini menunjukkan kondisi yang positif bagi kemajuan kebersamaan dan kerjasama tim. Adanya peningkatan usaha untuk berusaha dengan lebih baik lagi akan mendukung pencapaian prestasi olahragawan.

Dalam sisi yang lain pemberitaan negatif di media massa ternyata tidak membuat mereka menarik diri atau down. Sebaliknya pemberitaan negatif justru ada yang menjadi motivasi bagi mereka untuk menunjukkan bahwa mereka bisa lebih berprestasi lagi dan tidak seperti yang diberitakan. Selain itu juga menjadi koreksi bagi mereka untuk memperbaiki diri.

\section{Saran}

Saran-saran yang dapat diajukan dari simpulan dan implikasi penelitian ini adalah sebagai berikut:

1. Bagi olahragawan, bisa menjadi acuan untuk bagaimana mengolah informasi secara tepat, untuk mengembangkan motivasinya.

2. Bagi media massa, agar membantu olahragawan melalui konstruksi pemberitaan di media massa untuk membantu membangun motivasi olahragawan.

\section{Daftar Pustaka}

Albarran, Alan B. 2006. Handbook of Media Management and Economics. London: Lawrence Erlbaum Associates.

Ali Maksum. 2008. Psikologi olahraga Teori dan Aplikasi. Surabaya: Unesa University Press
Alfiasari Latifah M dan Wulandari A. 2011. Pengasuhan Otoriter Berpotensi Menurunkan Kecerdasan Sosial, Self Esteem Dan Prestasi Akademik Remaja. Penelitian IPB.

Alo Liliweri. 2011. Komunikasi Serba Ada Serba Makna. Jakarta: Kencana

Asep Rachmatullah. 2010. Falsafah Hidup Orang Jawa. Yogyakarta: Logung Pustaka.

Atkinson, Rita L, et all. 2010. Pengantar psikologi 1 (terjemahan Nurdjannah Taufiq - Agus Dharma). Jakarta: Penerbit Erlangga

Baran, Stanley J., dan Dennis K., Davis. (2012). Mass Communication Theory: Foundations, Ferment, and Future, Sixth Edition. Boston: Wadsworth.

Benoit, William L., Stephenson, Michael T., and Tschida, David A. (2001, Winter): Communication Studies 52.4. Retrieved May 20, 2003 from the Academic Search database.

BPPS. "Yogyakarta Dalam Angka" (PDF). BPS Kota Yogyakarta. Diakses 2012-12-19.

Bungin, Burhan. 2008. Sosiologi Komunikasi: Teori, Paradigma, dan Diskursus Teknologi, Komunikasi di Masyarakat. Jakarta: Kencana.

Butler, Richard J., 1996. Sport Psychology In Action. Boston: Butterworth-Heinemann

Butler, Richard J., 1999. Sports Psychology In Performance. Boston: Butterworth-Heinemann

Cangara, Hafied. 2006. Pengantar Ilmu Komunikasi. PT RajaGrafindo Persada, Jakarta

Compaine, Benjamin M., dan Gomery, Douglas. (2000). Who Owns the Media?: Competition and Concentration in the Mass Media Industry, Third Edition. London: Lawrence Erlbaum Associates.

Cox, RRichard H. 2007. Sport Psychology Concepts and Applications. USA: McGraw-Hill

Creswell, John W., 2015. Penelitian Kualitatif \& Desain Riset (terjemahan). Indonesia: Pustaka Pelajar

Curran, James, dan Gurevitch, Michael. 1992. Mass Media and Society. London: Edward Arnold.

Dainton, Marianne and Zelley, Elaine D. 2011. Applying Communication Theory for Professional Life; a Pratical Introduction. 2nd Edition. Thousand Oaks : SAGE Publications, Inc.

Denzin, Norman K, Lincoln, Yvonna S. 2009. Handbook of Qualitative Research. California: Sage Publication, Inc.

Dien Sumiyatiningsih, Kepemimpinan Pendidikan dalam Jender. Disertasi. PPs Unnes

Dustin A. Hahn, R. Glenn Cummins. 2014. Effects of Attractiveness, Gender, and Athlete-Reporter Congruence on Perceived Credibility of Sport Reporters. International Journal of Sport Communication, Volume 7, Issue 1, March. 2014, 7, 34-47

EM Griffin. 2012. A First Look At Communication Theory. Mc Graw Hill. Eriyanto. 2002. Analisis Framing. Yogyakarta: LKiS Yogyakarta

Eriyanto. 2005. Analisis Framing: Konstruksi, Ideologi, dan Politik Media. Yogyakarta: LkiS Pelangi Aksara.

Elijah G. Rintaugu, Peter, W. Mwangi dan Mwisukha Andanje. 2011. The influence of mass media in socialization into sport of Kenya secondary school athletes. International Journal of Current Research, Vol 3 issue 11, pp 471-475. ISSN: 0975-833X.

Groppel, J., Loehr, J., Melville, D. \& Quinn, A. 1989. Science of Coaching Tennis. Champaign: Leisure Press.

Hall, C.S. \& Lindzey, G., \& Campbell, J.B., 1998. Theories of Personality. New York; John Wiley \& Sons Inc.

Henderson, Harry. 2004. Power of The News Media. New York: Facts On File.

J. Eduardo Aguilar, Soledad Jorge, Ana Rubio dan G. Samuel Siris. 2011. Effect of mass media on suicidal behavior in patients with psychotic disorders. Mass media ISBN: 978-1-61728-863-0. Nova Science Publishers, inc,

Jalaluddin Rakhmat, M.SC. 2003. Psikologi Komunikasi. Bandung: 
Penerbit PT Remaja Rosdakarya

Jarvis, Matt. 2005. Sport Psychology. New York: Taylor \& Francis eLibrary

Jan Boehmer, Stephen Lacy. 2014. Sport News on Facebook: The Relationship Between Interactivity and Reader's Browsing Behavior. International Journal of Sport Communication, Volume 7, issue 1, March. 2014, 7, 1-15

Journal of Current Research, Vol 3 issue 11, pp 471-475, October 2011, ISSN: 0975-833X.

John W. Mahoney, Daniel F. Gucciardi, Nikos Ntoumanis, Cliff J. Mallett. 2014. Mental Toughness in Sport: Motivational Antecedents and Association with Performance and Psychological Health. JSEP, Volume 36 Issue 3, June. 2014, 26, 281-292, corrected July 7, 2014,

John Horne. 2005. Sport and The Mass Media in Japan. Sociology of Sport Journal, 2005. Volume 22, pp 415-432. USA; Human Kinetics

Jong Wu Jun., Hyung Min Lee. 2012. The Globalization of Sport and The Mass-Mediated Idendity of Hines Ward in South Korea. Journal Of Sport Management. Volume. 26. 103-112.

Jonothan Lewis, Jennifer M Proffit. 2012. Bong Hits and Water Bottles: An Analysis of News Coverage of Athletes and Marijuana Use. JSEP. Volume 7, Number 1, spring 2012 pp. 112|10.1353/jsm.2012.0009,

Journal of Sport Media, Volume 3, Number 1, Sping 2008, pp 1-25. Published by University of Nebraska Press. DOI 10.1353/jsm.2008.0003

JSEP, Volume 7, Number 1, spring 2012 pp. 1-12|10.1353/jsm.2012.0009,

JSEP, Volume 36 Issue 3, June. 2014, 26, 281-292, corrected July 7, 2014 ,

Karageorghis, Costas I; Terry, Peter C. 2011. Inside Sport Psychology. USA: Human Kinetics

King, L. A. 2007. The Science of Psychology An Appreciative View. New York: McGraw-Hill.

Larassari. 2010. Hubungan Antara Penerimaan Pesan Dari Media Massa Dan Pengetahuan Tentang Suplemen Dengan Konsumsi Suplemen Pada Olahragawan Persatuan Sepak Bola Indonesia Semarang (PSIS) Junior. Tesis UNDIP.

Laura Florentia Ghozali, Diah Krisnatuti, Alfiati. 2012. Hubungan Teman Sebaya Yang Berkualitas Dengan Dan Pemanfaat Media Massa Lam Meningkatkan Kecerdasan Sosial Olahragawan Muda. Penelitian. Departemen Ilmu Keluarga dan Konsumen, Fakultas Ekologi Manusia IPB.

Littlejohn, Stephen and Foss, Karen, A. 2008. Theories of Human Communication. Ninth Edition. Belmont, CA : Thomson Wadsworth.

Littlejohn, Stephen W. \& Foss, Karen A. 2009. Encyclopedia of Communication Theory. USA: SAGE.

Littlejohn, Stephen W. Foss, Karen A. 2009. Teori Komunikasi terjemahan (Theories of Human Communication). Jakarta: Salemba Humanika

Marris, Paul, dan Thornham, Sue. 2000. Media Studies: A Reader, Second Edition. New York: New York University.

Mass media ISBN: 978-1-61728-863-0 Tahun 2011, Nova Science Publishers, inc

May 20, 2003 from the Academic Search database. Wilcox, Dennis L., Cameron, Glent T,. Ault, Philip H., and Agee, Warren K. (2003). Public Relations Strategies and Tactics. Boston: Pearson Education Sumber

http://www.fisherhouse.com/courses/elaboration likelihood McQuail, Denis. 2005. Mass Communication Theory. Fifth Edition. London: Sage.

Mc.Quail, Dennis. 2005. Teori Komunikasi Massa. Jakarta: Erlangga
McQuail, Denis. 2011. Teori Komunikasi terjemahan (McQuail's Communication Theory. Jakarta: Salemba Humanika

Mehdi Moradi. 2012. Investigating the Role of Sport Media in developing Educational Sport. International Journal of Academic Research in Bussines and Sosial Sciences. Volume 2, No. 6 ISSN: 22-6990

Miles, Matthew B. Dan A. Michael Huberman. 1992. Analisis Data Kualitatif: Buku sumber tentang Metode-metode Baru. Terjemahan Tjetjep Rohendi Rohidi. Jakarta: UI.

Mohammadbagher Forghini Ozrudi, Mojtaba Bararzadeh, Mina Khanjani, Hamireza Fatahi. 2013. The role of mass media in studen's sport development at mazandaran province. International Journal of Sport Studies, Vol 3(1), 20-23. ISSN 2251-7502, Victor Quest Publication

Moleong. Lexy J. 2010. Metodologi Penelitian Kualitatif. Bandung: Penerbit Remaja Rosdakarya.

Monty P. Satiadarma. 2000. Dasar-dasar Psikologi Olahraga. Jakarta: PT Primacon Jaya Dinamika

Moore, Charlie. (2001, Fall). Elaboration Likelihood Model. Retrieved May 20, 2003 www.ciaadvertising.org/student account/fall 01.

Myers, David G. 1996. Social Psychology. New York: mcGraw-Hill Companies, Inc

Nurani Soyomukti. 2010. Pengantar Ilmu Komunikasi. Yogyakarta: Ar Ruzz Media

Nurudin. 2007. Pengantar Komunikasi Massa. Jakarta: Rajawali Pers

Ormrod, J. E. 2009. Educational Psychology Developing Learners. Merril Prentice Hall.

Poloma, Mararet. 2000. Sosiologi Kontemporer. Jakarta: Raja Grafindo.

Purwadi. 2008. Pranata Sosial Jawa. Yogyakarta: Tanah Air.

Rohendi, T.R., 2000. Ekspresi Seni Orang Miskin. Bandung: Nuansa. , 2000. Kesenian dalam pendekatan Kebudayaan. Semarang: STISI Bandung Press

Salman Farzalipour, Cengiz Akalan, Semiyha Tuncel, Behrouz Ghprbanzadeh, Mir Majid Kashef, Mehrdad Moharram Zadeh, Nayyer Hajizadeh. 2012. The role of mass media in women's sport. Scholars Research Library, European Journal of Sport and Exercize Science. Volume 1(1): 6-13. ISSN: 2278-005X,

Santrock, J. W. 2013. Educational Psychology (Vol. 5). (T. W. B.S., Trans.) Singapure: McGraw-Hill Company, Inc.

Sarjana Hadiatmaja dan Kuswa Endah. 2009. Pranata Sosial dalam Masyarakat Jawa. Yogyakarta: Grafika Indah.

Scott, Cynthia. (1996) "Understanding attitude change in developing effective substance abuse: Prevention programs for adolescents." School Counselor. 43.3. Retrieved

Schunk, D. H. 2012. Learning Theories An Educational Perspective. Boston: Allyn \& Bacon, 501.

Scholars Research Library, European Journal of Sport and Exercize Science, 2012, 1(1): 6-13. ISSN: 2278-005X,

Sheard, Michael. 2013. Mental Toughness. New York: Routledge Tailor and Francis Group

Sherlley Wigley, Patrick C. Meirick. 2008. Interactive Media and Sport Journalist: The Impact of Interactive Media on Sports Journalist diterbitkan dalam Journal of Sport Media. Volume 3, Number . pp 1-25. Published by University of Nebraska Press. DOI 10.1353/jsm.2008.0003.

Shoemaker, Pamela J., dan Reese, Stephen D. 1996. Mediating the Message: Theories of Influences on Mass Media Content, Second Edition. New York: Longman 